\title{
A Rare Case of Extrahepatic Left Hepatic Duct Diverticulum: Case Report with Literature Review
}

\author{
Hwaseong Ryu' ${ }^{1}$, Tae Un Kim¹, Jin Hyeok Kim¹, Jieun Roh¹, Jeong A Yeom¹, Hee Seok Jeong ${ }^{1}$, Je- Ho Ryu², \\ Hyeong Seok Nam ${ }^{3}$ \\ ${ }^{1}$ Department of Radiology, ${ }^{2}$ Division of Hepato-Biliary-Pancreatic Surgery and Transplantation, Department of Surgery, ${ }^{3}$ Division of Gastroen- \\ terology, Department of Internal Medicine, Pusan National University Yangsan Hospital, Yangsan, Korea
}

Hepatic duct diverticulum is a rare form of choledochal cyst that does not fit into the most widely used Todani classification system. Because of its rarity, it may be difficult for clinicians to diagnose and treat it. Here, we present a case of left hepatic diverticulum in a 57-year-old woman with epigastric pain. At presentation, there were mild elevations in the liver function tests. Computed tomography and magnetic resonance cholangiopancreatography showed diverticulum-like cystic lesion with sludge ball near the confluence portion of both intrahepatic bile duct, but the origin of the lesion could not be identified. The clinical impression was type II choledochal cyst. Surgical excision was planned due to recurrent abdominal pain. The operative findings revealed diverticulum arising from left hepatic duct. Histopathology confirmed the lesion to be diverticulum lined by biliary epithelium. The patient had no postoperative complication and no further symptoms since the operation.

Korean J Pancreas Biliary Tract 2019;24(1):31-34

Keywords: Choledochal cyst, Bile ducts, Magnetic resonance cholangiopancreatography, Diverticulum

\author{
Received Jun. 8, 2018 \\ Revised Oct. 1, 2018 \\ Accepted Oct. 6, 2018
}

Corresponding author :Tae Un Kim Department of Radiology, Pusan National University Yangsan Hospital, 20 Geumo-ro, Mulgum-eup, Yangsan 50612, Korea

Tel. +82-55-360-1840 Fax. +82-55-360-1848

E-mail; kimtaeun78@hanmail.net

ORCID: https://orcid.org/0000-0003-1017-6926

\section{INTRODUCTION}

Choledochal cysts are uncommon disease, which are defined as cystic dilatation of any portion of the bile ducts. The Todani classification based on the cholangiographic morphology, location, and number of intrahepatic and extrahepatic bile duct cysts is the most widely accepted. Type I cysts involve only extra- hepatic biliary system and are the most frequent type. They are subdivided into IA (involve the entire extrahepatic bile duct), IB (segmental involvement of the extrahepatic bile duct), and IC (diffuse, fusiform, or cylindrical involvement of the extrahepatic bile duct with anomalous pancreaticobiliary ductal union). Type II cysts are true diverticula of the extrahepatic duct, usually occurring in the common bile duct. Type III cysts, also known as 
choledochoceles, are in the extrahepatic bile duct within the duodenal wall. Type IV cysts include type IVA (multiple extra and intrahepatic cysts), and IVB (multiple extrahepatic cysts). Type V cysts only involve the intrahepatic bile duct. ${ }^{1-4}$ Unlike these choledochal cysts, hepatic duct diverticula are true diverticula arising from hepatic duct and they does not fit into the Todani classification system. In this report, we present a case of unusual diverticulum arising from left hepatic duct with sludge ball.

\section{CASE}

A 57-year-old woman presented with recent epigastric discomfort for one month. She had no specific past or family history. At presentation, there was no abnormal finding in the blood tests except mild increase of aspartate aminotransferase (136 IU/L), alanine aminotransferase (37 IU/L), alkaline phosphatase (136 IU/L). Abdominal computed tomography (CT) images revealed a $2.0 \mathrm{~cm}$ thin-walled cystic lesion containing non-enhancing high attenuation area in the porta hepatis (Fig. 1). Both intrahepatic bile ducts (IHDs) and common bile duct (CBD) were not dilated. Despite one month of conservative treatment, her intermittent abdominal pain was persisted. For further evaluation, magnetic resonance cholangiopancreatography (MRCP) was performed. MRCP showed diverticulum-like cystic lesion

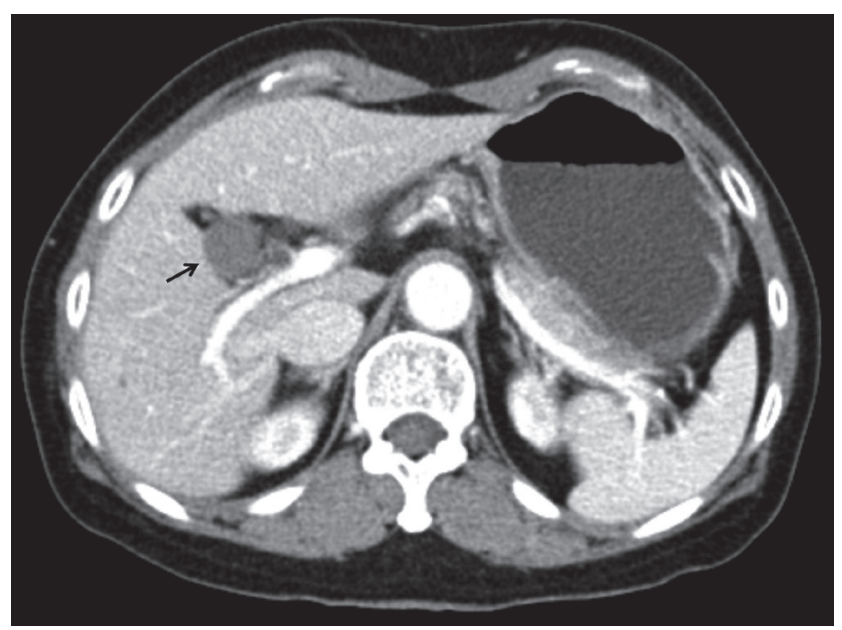

Fig. 1. Contrast enhanced axial abdominal computed tomography images show a round cystic lesion (arrow) containing non-enhancing higher attenuation area in the porta hepatis. with sludge ball near the confluence portion of both IHD, but the exact origin of the lesion could not be identified. There was no anomalous pancreaticobiliary ductal union (APBDU) (Fig. 2). The initial impression was Todani's type II cyst with sludge ball or hemorrhagic hepatic cyst. Surgical excision was performed because of her recurrent abdominal pain. At laparotomy, a 2.2 $\mathrm{cm}$ diverticulum containing biliary sludge arising from the extrahepatic portion of the left hepatic duct was found (Fig. 3). Subsequently, excision of diverticulum, and cholecystectomy were performed. Intraoperative cholangiography showed no APBDU, nor bile leakage. Histopathologic examination confirmed the presence of biliary epithelium lining the cystic lesion, which finding is consistent with biliary diverticulum (Fig. 4). But no inflammatory cell infiltration was observed on the specimen. The patient was discharged on 8th postoperative day without any postoperative complication and no further symptoms since the operation.

\section{DISCUSSION}

Hepatic duct diverticulum is considered to be very rare developmental anomaly. ${ }^{5}$ Although the exact etiology is not well known, some reports have proposed that hepatic diverticulum

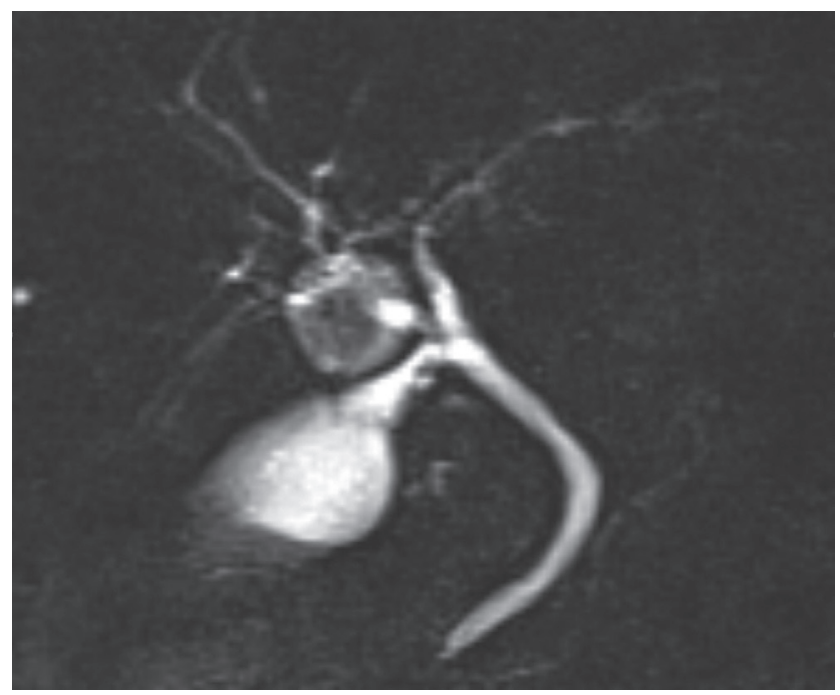

Fig. 2. Magnetic resonance cholangiopancreatography images demonstrate round cystic lesion with sludge ball near the confluence portion of both IHD. There is no anomalous pancreaticobiliary ductal union. IHD, intrahepatic bile duct. 
may be incompletely developed shunt from proximal hepatic duct to the CBD below the cystic duct. ${ }^{6,7}$ Given this etiological theory, diverticulitis caused by bile flow shunt and stasis may result in abdominal pain. ${ }^{8}$ Kaneyama et al. ${ }^{9}$ reported one patient with right hepatic duct diverticulum. Their patient had recurrent right upper abdominal pain, and histopathologic examination showed inflamed biliary diverticulum. This supports the hypothesis that local inflammation of hepatic diverticulum can be a cause of abdominal pain. But according to one autopsy study, similar hepatic duct anomalies can be found in $8 \%$ of individuals, suggesting most cases are asymptomatic. ${ }^{10}$ In our case, no definite inflammatory change of hepatic diverticulum was detected on histopathology but symptom of patient was improved after surgical excision.

Only a few cases of hepatic duct diverticulum have been reported to date (Table 1). All patients were women with various ages, and presented with abdominal or back pain except for one infant patient. And most patients had right hepatic duct diverticulum. Only one case of left hepatic diverticulum was reported,

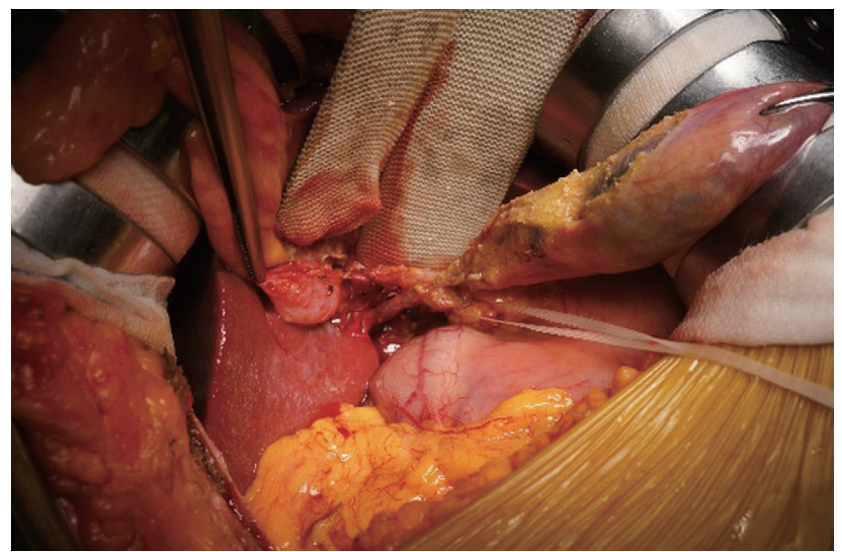

Fig. 3. On laparotomy, a $2.2 \mathrm{~cm}$ diverticulum containing biliary sludge arising from the extrahepatic portion of the left hepatic duct was found. but it had two separate stalks arising from LHD and CHD, which was different from our case. None of the previously published cases described ABPDU. ${ }^{8,9,11,12}$

Various imaging modalities for preoperative evaluation of choledochal cyst are now available, such as CT, MRCP, ultrasonography, hepatobiliary scan, percutaneous transhepatic cholangiography, and endoscopic retrograde cholangiopancreatography (ERCP). ${ }^{13}$ Hepatic duct diverticula can be confused with other cystic lesions such as hepatic cysts, enteric duplication cysts, hepatic artery aneurysm, and duplication anomalies of gall bladder. ${ }^{14}$ Preoperative MRCP and ERCP can be helpful in diagnosis of bile duct diverticulum, and establishment of surgical plan. ${ }^{8}$ Hashimoto et al. ${ }^{5}$ reported that ERCP is the most effective for diagnosis of bile duct diverticulum. But in cases with uncertain preoperative diagnosis, intraoperative cholangiography is needed.

There is no established treatment for hepatic duct diverticulum. Reviewing published case reports, all cases were treated

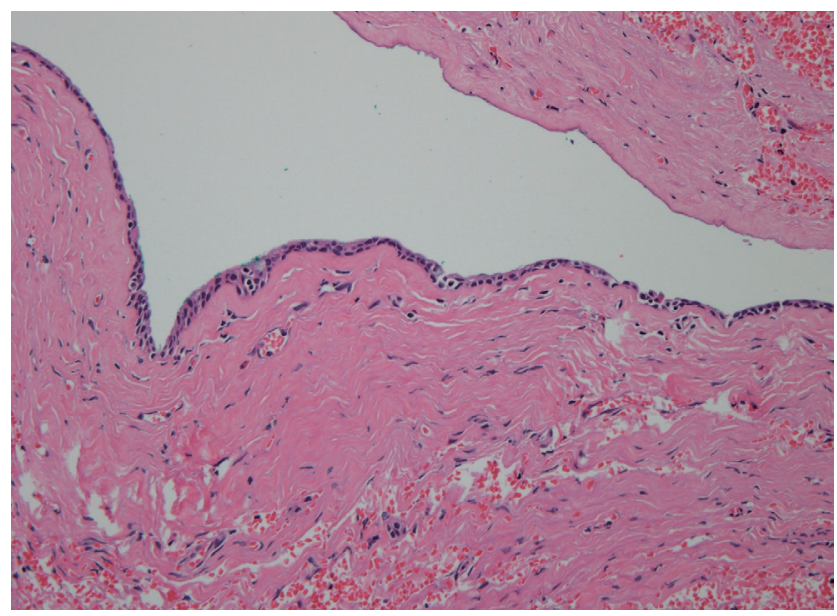

Fig. 4. Histopathology of the resected specimen showed cystic lesion lined with biliary epithelium lacking of muscle layer $(H \& E, x 200)$.

Table 1. Previous reports of hepatic duct diverticulum

\begin{tabular}{lccllc}
\hline Study & Age & Sex & Symptoms & Location & ABPDU \\
\hline Meyers et al. ${ }^{11}(1976)$ & 25 years & F & Recurrent epigastric pain & Right IHD & - \\
Kaneyama et al. ${ }^{9}(2005)$ & 17 years & F & Recurrent right upper abdominal pain & Right IHD \\
\hline Fernandes et al. ${ }^{12}(2010)$ & 57 years & F & Upper abdominal pain, nausea, and vomiting & Right IHD & No \\
Salles et al. ${ }^{14}(2013)$ & 7 months & F & Antenatal diagnosis & Right IHD & - \\
Huang et al. ${ }^{8}(2015)$ & 4 years & F & Recurrent epigastric and right abdominal pain & Left IHD (two stalks from CHD and left IHD) & No \\
\hline
\end{tabular}

ABPDU, anomalous pancreaticobiliary ductal union; IHD, intrahepatic bile duct; $C H D$, common hepatic duct. 
with surgical excision, and no further symptoms were reported (Table 1). Total excision of diverticulum would be good treatment option in symptomatic patients who can justify morbidity expected from surgical intervention. ${ }^{12}$

In conclusion, we reported an unusual left hepatic diverticulum not included current Todani's classification. Because of its rarity, little is known about hepatic duct diverticulum. Further studies are required to establish new classification, and to select ideal diagnostic modality, and treatment of hepatic diverticulum.

\section{요 약}

담관의 게실은 Todani 분류에 부합하지 않는 드문 형태의 담관의 낭성 확장이며, 질환의 희소성으로 인하여 진료 현장 에서 진단이나 치료에 어려움을 겪을 수 있다. 본 증례보고 에서는 복통을 주소로 내원한 57세 여성 환자에서 발생한 간외 좌측 담관 게실의 증례를 문헌고찰과 함께 보고하고자 한다. 내원 당시 환자는 간기능 검사에서의 경미한 증가 외에 혈액 검사상 이상 소견은 보이지 않았다. 전산화단층촬영과 자기공명 담도췌관조영술에서 간내담관의 합류 부분 근처에 슬러지 볼을 포함한 낭성 병변이 보였으나 병변의 기원은 명확히 보이지 않았다. 임상적으로는 Todani II형 총담관낭이 의심되었다. 환자의 복통이 지속되어 해당 병변에 대하여 수술적 절제를 시행하였고 수술 결과 좌측 담관 게실로 진단되었다. 절제된 조직은 병리학적 검사상 담도 상피로 덮인 게실로 확인되었다. 수술 후 합병증은 발생하지 않았으며 수술적 제거 후 환자의 증상은 호전되었다.

국문 색인: 총담관낭, 담관, 자기공명담관이자조영술, 게실

\section{Conflicts of Interest}

The authors have no financial conflicts of interest.

\section{REFERENCES}

1. Todani T, Watanabe Y, Narusue M, Tabuchi K, Okajima K. Congenital bile duct cysts: classification, operative procedures, and review of thirty-seven cases including cancer arising from choledochal cyst. Am J Surg 1977;134:263-269.

2. Lee HK, Park SJ, Yi BH, Lee AL, Moon JH, Chang YW. Imaging features of adult choledochal cysts: a pictorial review. Korean J Radiol 2009;10:71-80.

3. Jabłońska B. Biliary cysts: etiology, diagnosis and management. World I Gastroenterol 2012;18:4801-4810.

4. Nambiar L, Alex A, Siskind E, et al. Type VI choledochal cyst-an unusual presentation of jaundice. Int J Angiol 2016;25:263-265.

5. Hashimoto M, Umemura R, Okuda C, Matsuda M, Watanabe G. Hepatic duct diverticulum. Am J Surg 2007;193:219-220.

6. Schey WL, Pinsky SM, Lipschutz HS, Dragomer AS. Hepatic duct diverticulum simulating a choledochal cyst. AJR Am J Roentgenol 1977;128:318-320.

7. Maxwell JW Jr, Jackson FC, Davis WC, Eisen HB, Poller S. Hepatodochal diverticulum: a new entity. Am Surg 1967;33:153-158.

8. Huang SY, Chen HC, Chou CM. Diverticulum arising from the left hepatic duct. J Formos Med Assoc 2015;114:666-667.

9. Kaneyama K, Yamataka A, Urao M, Kobayashi H, Lane GJ, Miyano T. An extremely rare case of symptomatic right hepatic duct diverticulum located outside the liver. Pediatr Surg Int 2005;21:1023-1026.

10. Eisendrath DN. Operative injury of the common and hepatic bile ducts. Surg Gynec Obstet 1920;31:1-18.

11. Meyers C, Reynes CJ, Freeark RJ. Diverticulum of the hepatic duct: a rare anomaly. Radiology 1976;119:38.

12. Fernandes ES, Bernardo RL, Fernandes MM, et al. Extrahepatic right hepatic duct diverticulum: a rare entity. Hepatobiliary Pancreat Dis Int 2010;9:213-215.

13. Kim JY, Kim HJ, Han HY. A case report of an unusual type of choledochal cyst with choledocholithiasis: saccular dilatation of the confluent portion of both intrahepatic ducts. J Korean Soc Radiol 2015;73:252-258

14. Salles A, Kastenberg ZJ, Wall JK, Visser BC, Bruzoni M. Complete resection of a rare intrahepatic variant of a choledochal cyst. J Pediatr Surg 2013;48:652-654. 